\title{
Meaningful Learning in Discussion Forums: Towards Discourse Analysis
}

\author{
Raafat George Saadé and Qiong Huang \\ John Molson School of Business, Concordia University, \\ Montreal, Quebec, Canada
}

\author{
rsinfo@sympatico.ca; qiongh@gmail.com
}

\begin{abstract}
This document presents the analysis of a discussion forum used as a learning component in a 'management information systems' university course. By reporting on two macro level measures namely, participation and interaction, we seek to understand the occurrence of any collaborative know ledge-building activities/processes and at the same time work towards discourse analysis. Our analysis is based on the qualitative case study approach.

Participation and interaction analysis from student usage of the discussion forum provide some insight into their learning and behavior in a virtual environment. Students spent time on reading forum discussions, reflecting and planning their contribution before posting it in the forum. Moreover, their participation behavior throughout the semester follows an s-curve, interestingly, typical in adoption theory studies.
\end{abstract}

Keywords: Online discussion forums, discourse, participation, interaction, elearning, online, asynchronous

\section{Introduction}

Computer mediated communications (CMC) was and remains a driving force towards new forms of asynchronous discussion, which constitutes a significant and very important component in distance learning. Since 1998, analys is of asynchronous learning environments shows that computer conferencing accounts for $40 \%$ of the online environment and for $80 \%$ of what is described as 'learning with others' (Bourne, 1998, Schrire, 2006). Today, continuous learning is a vital matter. This is because our fast past world driven by the hyper-evolution of technologies necessitates the continuous learning of one's profession, upgrading new skills and making sense of our information overloaded everyday life. To that effect, we find ourselves a part of many networks that are essentially organizational forms and which are as of today, not the tried and true settings of yesteryear (Desanctis et al., 2003).

Material published as part of this publication, either on-line or in print, is copyrighted by the Informing Science Institute. Permission to make digital or paper copy of part or all of these works for personal or classroom use is granted without fee provided that the copies are not made or distributed for profit or commercial advantage AND that copies 1) bear this notice in full and 2) give the full citation on the first page. It is permissible to abstract these works so long as cred it is given. To copy in all other cases or to republish or to post on a server or to redistribute to lists requires specific permission and payment of a fee. Contact Publisher@InformingScience.org to request redistribution permission.
Learning networks provide opportunities to seek, obtain, and provide information. Moreover, in learning networks, relationships among participants can be formed in a culturally diverse global environment facilitated by its inherent nature of operating across space and time. Many questions about the effectiveness of learning networks are raised. Can people effectively share information? Can they work together in this 
asynchronous virtual environment? Can their interactions result in enhanced understanding and develop insight? All these questions remain.

Online discussion forums (ODF) are a web-based application that has been used extensively to bring people together with shared interests and mind-set. In education, they have been deployed to complement traditional techniques such as lectures and tutorials (Dube et al., 2006, Yang et al., 2007). ODFs harmonize with the educational philosophy that considers communication a necessary and fundamental mechanism for effective learning (Harman \& Koohang, 2005; Wallace, Jagose, \& Gunn, 2003). It was found that learners' interaction with both human and inanimate objects, and their participation in technology mediated education, were essential for the quality of their learning experience, can enrich the process of knowledge exchange among participants and has positive effects on the student's performance (Keller, 1987; Leidner \& Jarvenpaa, 1995;

Zhang et al., 2006). Consequently ODFs can be successful in enhancing collaborative learning by attracting students to participate and interact (Swan et al., 2000).

Understanding the discourse that occurs in ODFs in the teaching-learning context requires some methodological approach to measure and analyze data and information and permitting for both analytical and holistic perspectives (Schrire, 2006). In this paper, we base our theoretical framework on Schrire (2006) who uses the qualitative study approach (Merriam, 2001). We report on our investigation of an ODF used as one learning component of a management of information systems course in a higher education institution. By performing a macro-level analys is of performance and interaction within the context of the course, it was possible to better understand whether learning did occur and holistic behavior of students. Based on the presented work, we continue our research in analyzing the ODF qualitative content by performing a fine grained discourse analysis.

\section{Theoretical Framework}

\section{Discussion Forums \& Discourse}

Discussion forums (DF) were first introduced in the mid 1980s as a form of asynchronous electronic communication. Discussion forums are broadly used nowadays to connect people (globally) with the same interests in one virtual space. Most discussion forums are unstructured and open ended in function which serves as an outlet of ideas and thoughts of members. Discussion forums can be political, health related, educational, technical support, game related and in general a virtual place to share ideas and resources. By virtue of its nature, discussion forums are difficult to structure and to moderate. This is because in order to do so, they require a large amount of effort, resources and time. Defining and achieving a desired outcome from discussion forums is complex (Henri, 1992; Irani, 1998; Ma, 2008).

Nevertheless, discussion forums have been used for educational purposes as a tool for promoting different modes of learning that can lead to enhanced learning outcomes for students (Montero et al., 2007). Discussion forums can be online collaborative learning spaces in which students engage in the discourse on a topic about which they are motivated (intrinsically and/or extrinsically) by common goals. The interactions produced can facilitate student involvement in authentic communication in a real learning context where relationships with other students of different backgrounds and experiences may be developed (Sutherland et al., 2003). The collaborative work carried out in a learning discussion forum community develops a common ground of know ledge, putting into practice authentic tasks, know ledge building and/or reflection.

Asynchronous discussion provides opportunities for collaborative learning and teaching transactions that can be dialogic in nature. To the same extent that oral speech is central to face-to-face classroom interaction (Singh et al., 2007; Wells, 1999), so is electronic discourse, a write-talking 
characteristic of online interaction (Davis \& Brewer, 1997). This online interaction is central to the development of the instructional process in asynchronous computer discussion. The significance of discourse in the learning process is anchored in the theories that view the development of thought to be mediated by social discourse (Vygostky, 1962; Wertsch, 1998).

Understanding the electronic discourse produced in asynchronous discussion forums in the teaching-learning context requires the adoption of a methodological approach permitting both analytic and holistic perspectives (Schrire, 2006). In this research, the purpose was to ultimately arrive at explaining the discourse that occurred during one session, within a specific online learning context. In order to do that, the concepts found in asynchronous forum discourse need to be operationalized.

\section{Operationalization of Concepts}

It is necessary to base the operationalization of concepts in asynchronous discussion forums on theories of collaborative learning (De Wever et al., 2005). Theoretical models of collaborative learning consider the discourse in asynchronous discussion forums as both reflecting and shaping the cognitive processes. Moreover, the cognitive processes are of a social nature in the sense that they arise out of, and contribute to, the interaction among the participants. Dimensions of the learning situation and knowledge building in asynchronous discussion forums are: the interactions among the learners, the character of their discourse, and the individual and socially distributed cognitions characterizing the learning process in the online group (Schrire, 2006). The operational definitions are given in Table 1:

\begin{tabular}{|c|c|c|c|}
\hline \multicolumn{4}{|c|}{$\begin{array}{c}\text { Table 1. Operational Definitions of Knowle dge Buil ding Dimensions. } \\
\text { (Highlighted is used for present anal ysis) }\end{array}$} \\
\hline Type & Level & Analys is & Description \\
\hline Participation & Macro & Totals & $\begin{array}{l}\text { Involves number or average length of messages } \\
\text { posted. }\end{array}$ \\
\hline Interaction & Macro & Thread Patterns & $\begin{array}{l}\text { Three forms: Student-content; student-teacher; } \\
\text { student-student (Garrison \& Anderson, (2003). It } \\
\text { is the component that defines the educational } \\
\text { process and is essential for meaningful learn ing, } \\
\text { and contributes to the development of argumen- } \\
\text { tative reasoning conducive to inquiring multiple } \\
\text { facets of complex problems (Weinberger \& } \\
\text { Fischer, 2005). }\end{array}$ \\
\hline Interaction & Micro & $\begin{array}{l}\text { Discourse Analy- } \\
\text { sis, Socio- } \\
\text { Linguistic Analysis }\end{array}$ & $\begin{array}{l}\text { Learning is characterized as conversation } \\
\text { (Sherry et al., 2000). Depending on the purpose } \\
\text { of the learning situation (transactional, trans- } \\
\text { forming or transcendent), different types of con- } \\
\text { versation will result (dialectic, discussion, dia- } \\
\text { logue and design). }\end{array}$ \\
\hline Cognition & Micro & $\begin{array}{c}\text { Multi- } \\
\text { typology/taxonomy } \\
\text { Analysis }\end{array}$ & $\begin{array}{l}\text { Presence of critical thinking (Deziel-Evans, } \\
\text { 2000). Includes indicators of deep learning and } \\
\text { in-depth cognitive processing and collaborative } \\
\text { knowledge building (Laurillard, 1979, Henri, } \\
\text { 1992). }\end{array}$ \\
\hline
\end{tabular}

In this article we limit our study to understanding participation and interaction of students as we keep our analysis at the macro level. 


\section{The Learning Management System}

The Learning Management System (ELMS) is a web-based course components management system. The ELMS used was presented in more details in Saadé and Huang (2008); however, we will provide a review of its functionality and elaborate on the forum component used for learning since this component is the core subject of this article.

The ELMS is not a typical 'content management system', but rather provides agile courses management functionalities and learning tools with measurable learning outcomes. Such tools include an educational information system for enhanced learning (EISEL-first prototyped and published in Saadé, 2003), a virtual collaborative and peer-to-peer testing environment (VLE), a virtual (wiki based) collaborative environment for project development, an interactive computer aided learning (ICAL) tool, higher order thinking learning tool (reflective and know ledge building activities), and a self maintaining forum (SMF).

These learning tools are part of a larger enterprise-wide learning management system with an integrated backend that allows 'data chunks' to be reused and recycled. This ELMS has been used for a core course in Management Information System (8 years), an entry course in Fundamental to Information Technology (4 years) and now for a Business Statistics course (prototype in Fall 2008) and is the platform used for many different studies (Saadé \& Bahli, 2005: Saadé \& Kira, 2007). Evidently, the ELMS has evolved over the past 8 years and its evolution is guided by measuring its effectiveness in achieving learning outcomes and optimizing student learning experience.

Due to limitation of space and the more detailed description of the ELMS found in Saadé and Huang (2008) we will limit our presentation to its functionality from a student perspective. To that effect, the course marking scheme (shown in Figure 1) is the central point for the teaching

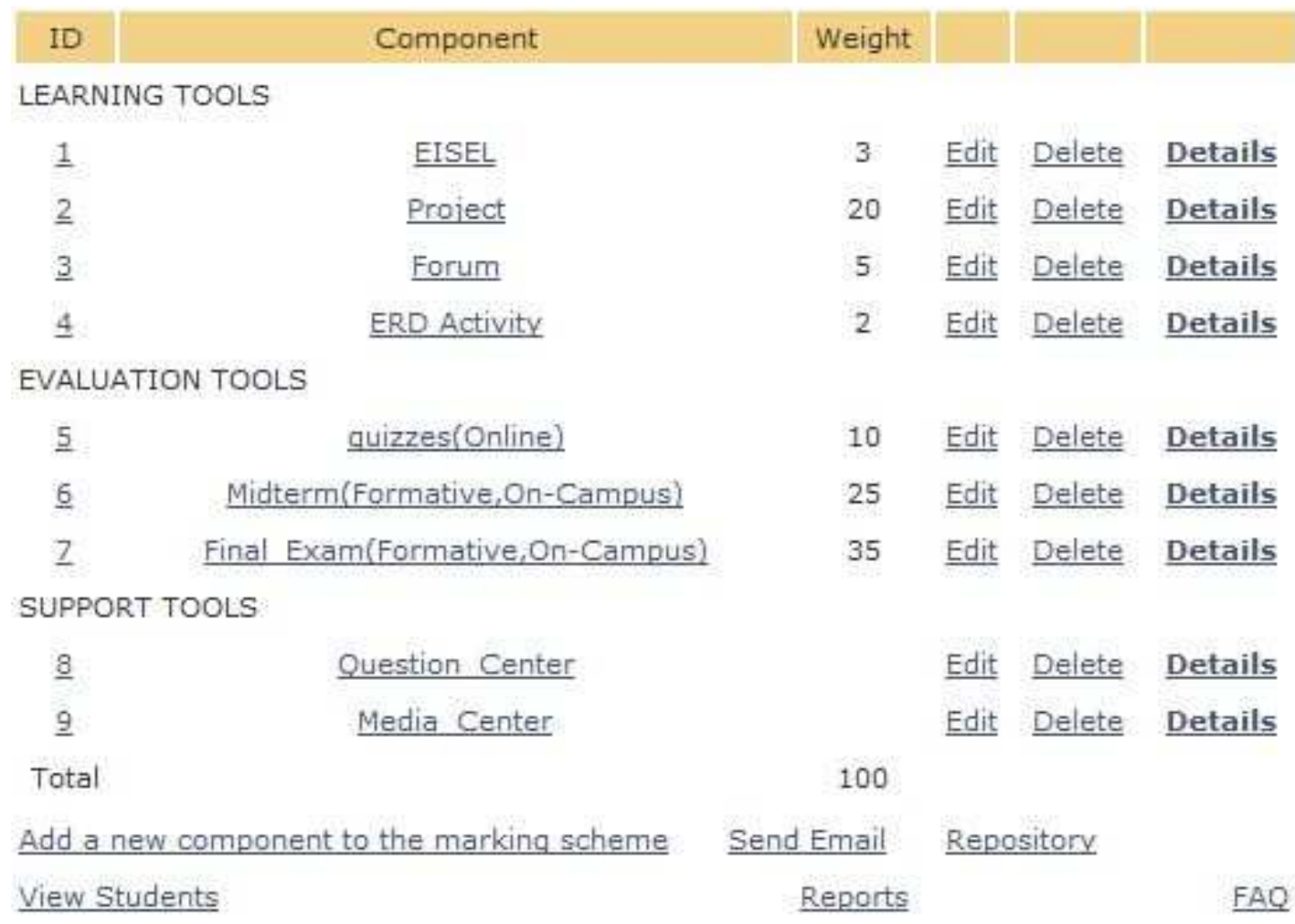

Figure 1. Student View of Main Course Page in the ELMS. 
plan scheduling and is the main view for the student. All teaching tasks and learning objects are organized in this view. This student view includes three primary components, namely for learning, assessment and support. The learning component includes learning tools to practice questions (EISEL), a collaborative zone to work in virtual groups for the development of a project (project), a forum (the subject of this article) for discussion and content-relevant know ledge creation and an entity re lationship diagram (ERD) activity focused on teaching the concept of database design. The assessment component includes formative (online) quizzes and summative (physically present) midterm and final exam. The support component entails a question center which helps students reflect on their question by providing some relevant metadata as well as serve as a screening of question to redirect to appropriate person to answer such as technical support, teaching assistant or professor.

\section{Methodology}

\section{Context}

The ELMS was developed in-house and is being used today for three online courses, Management Information System (MIS), Fundamental of Information Technology (FIT), and Business Statistics, at the John Molson School of Business, Concordia University, Montreal, Quebec, Canada. The ELMS today is the product of six years of action research evolution, the first version was published in Saadé (2003).

The present article looks at one part of the ELMS (Saadé \& Huang, 2008), namely the forum discussion and attempts to understand the behavior of students in this forum over a period of one semester. Three hundred students were enrolled in an MIS core course. Students taking the MIS courses were mostly second or third year students. The course pedagogy is constrained because it is a coordinated course with 5 other face-to-face sections being taught in the same semester. The coordination implied that the midterm and the final exams were common and the coordinator makes the decision on how the exams are composed. Moreover, the correction of the exams is common to ensure consistency. This means that each teacher is assigned a number of questions which he/she corrects for all the sections. In the present case, the midterm and final exams constituted $60 \%$ of the final grade of the students. $40 \%$ of the grade entailed online activities $35 \%$ or which were assessment and 5\% participatory. This 5\% of the grade is dedicated to the forum. Figure 1 above provides a view of the main course interface and its learning, evaluation and support components.

\section{Procedure}

Asynchronous discussions as part of the online course alone are facilitated by the forum shown in Figure 2. Although discussions ideally should occur between teacher-student and student-student, the design of the forum usage is constrained due to the large number of students. Different from common open ended forums, the ELMS forum is well-defined and structured. Participation on forum is monitored by ELMS. The forum participation includes the following framework (as per the instructions to the students):

The forum is made up of 3 parts namely contribution to an MIS case problem, contribution to my lectures and contribution to your peers' cases/problems [total $5 \%$ ]. Contribution case $1=1.5 \%$ Contribution case $2=1.5 \%$ Contribution one per lecture $1 \%$ each. Contribution for any 4 peer cases $=1 \%$. Top 50 cases in popularity get extra 10\% on forum percent. I may have 5 or 6 lectures. So the total posts for my lectures that you need to make is minimum 6. One for each lecture. This gives you a total of $6+2+4=12$ posts. When you post your problems/case please address the 
following sections/titles: 1. Give it a title/name. 2. Which chapter(s)from the book that it addresses: Identify the chapter(s) that deals with your problem. 3. Situation. 4. Problem. 5. Solution if it was solved. Discuss ideas, suggestions, or thoughts if it was not. 6. Reasoning. 7. Conclusions/lessons learned. Please follow the format above. Do notforget that each case is worth $1.5 \%$ so it is rather significant. Due date for cases is last day of classes. But the earlier you post them the more hits/replies you getfrom classmates and chances of being from the top 50 and gain your extra points.

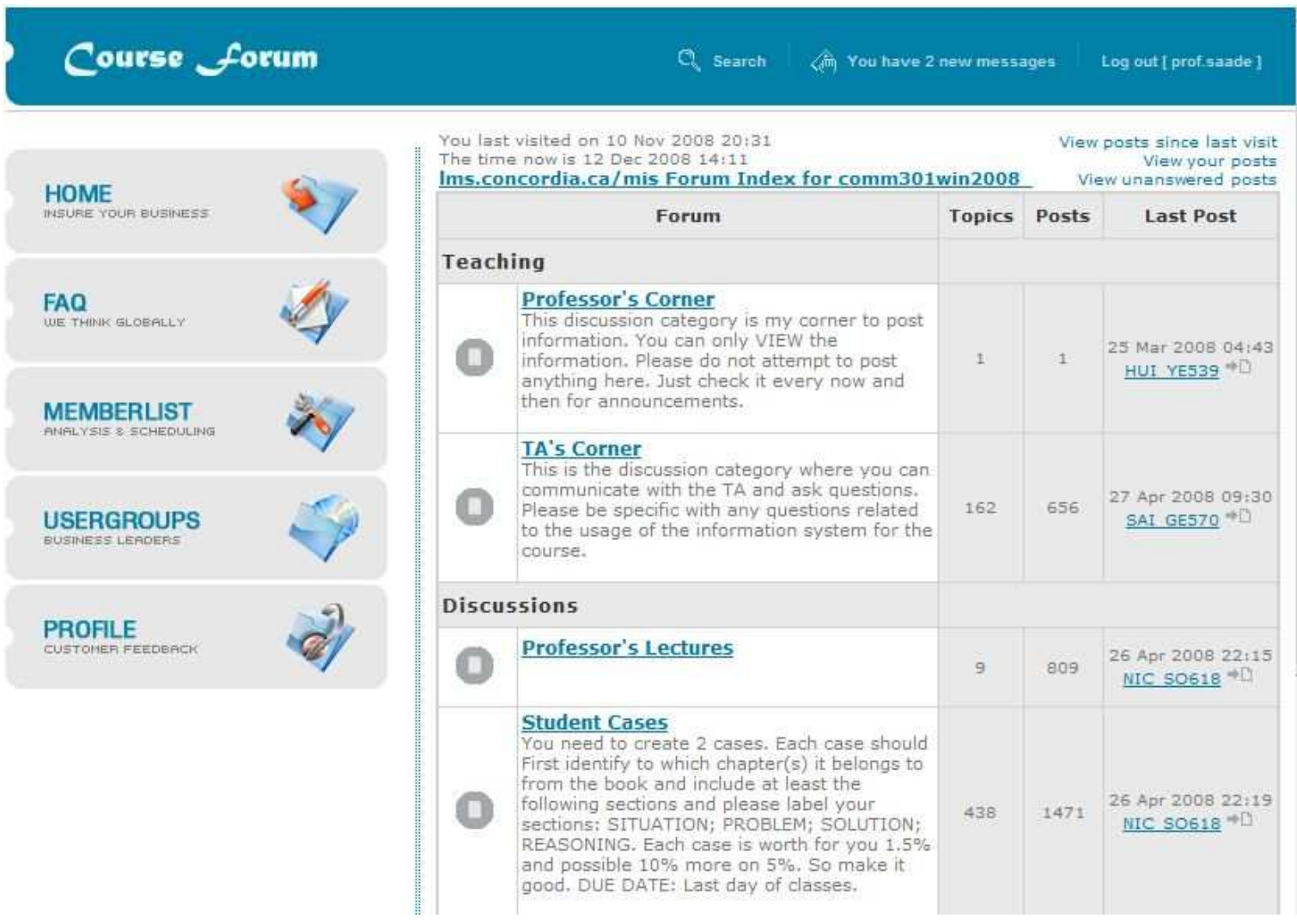

Figure 2. Main Page of the Dis cussion Forum

Therefore, in essence the forum includes two primary sections for learning. The first is the professor's lectures and the second is the student cases. The professor's lectures include real life experiences with questions embedded, that students need to discuss and possibly share their own experiences. At a minimum, each student is required to post one discussion but is encouraged to participate further in discussion they are attracted to. In the student cases section, students are asked at a minimum to create two cases and participate in four cases created by peers. This creates a situation where students need to look at all available cases and read them and then decide which ones interest them enough to participate in. A motivation to capture more points was integrated into the pedagogy to encourage students to take the time to produce interesting cases and discussions.

The result of the problems/cases (and primary subject of our analysis in this article) created by the students is shown in Figure 3. The forum learning tool provides us with the topic created, number of replies, and number of views. It is interesting to note that number of views are signif icantly higher that number of posts, indicative that students are reading the cases posted by others and are actually looking for a topic that is interesting to them for contribution. 


\begin{tabular}{|c|c|c|c|c|c|}
\hline \multicolumn{6}{|c|}{ Moderators: None } \\
\hline \multicolumn{5}{|c|}{$\begin{array}{l}\text { Ims.concordia.ca/mis Forum Index for } \\
\text { comm301win2008 } \rightarrow \text { Student Cases }\end{array}$} & Mark all topics read \\
\hline & Topics & Replies & Author & Views & Last Post \\
\hline $\mathbf{0}$ & $\frac{\text { Potholes in Montreal }}{[\text { Goto page: } \underline{1}, \underline{2}]}$ & 21 & SAN MA604 & 61 & $\begin{array}{l}26 \text { Apr } 200822: 19 \\
\text { NIC } 50618\end{array}$ \\
\hline 0 & Online Banking & 3 & DEN KA604 & 11 & $\begin{array}{l}26 \text { Apr } 200822: 19 \\
\text { NIC S0618 }\end{array}$ \\
\hline $\mathbf{Q}$ & $\begin{array}{l}\text { Parkina Full! } \\
{[\text { [Goto page: } 1, \underline{2}]}\end{array}$ & 24 & $\underline{\text { LAU KO570 }}$ & 95 & $\begin{array}{l}26 \text { Apr } 200822: 18 \\
\text { NIC } 50618\end{array}$ \\
\hline Q & Bluetooth & 2 & KAM NAG02 & 12 & $\begin{array}{l}26 \text { Apr } 200822: 17 \\
\text { NIC } 50618\end{array}$ \\
\hline B & $\begin{array}{l}\text { "RATE MY PROFESSORS .COM " chapter } 15 \text {, } \\
\text { b7 DGoto page: } \underline{1}, \underline{2}, \underline{3}, \underline{4}]\end{array}$ & 57 & THO BE615 & 303 & $\begin{array}{l}26 \text { Apr } 200822: 16 \\
\text { NIC } 50618 \rightarrow D\end{array}$ \\
\hline 0 & $\frac{\text { Online Gambling chapter } 14}{[\text { G Goto page: } 1,2]}$ & 15 & JOS AU618 & 47 & $\begin{array}{l}26 \text { Apr } 200822: 16 \\
\text { NIC } 50618\end{array}$ \\
\hline Q & $\begin{array}{l}\text { Online shoppinq-DANGER???(ch14) } \\
{[\text { DGoto paget } 1,2]}\end{array}$ & 22 & NIN MA616 & 122 & $\begin{array}{l}26 \text { Apr } 200822: 15 \\
\text { NIC } 50618\end{array}$ \\
\hline 0 & $\frac{\text { (ch14)ONLINE DATING.....hmmmmm............... }}{[\text { [Goto page: } 1,2]}$ & 20 & NIN MA616 & 143 & $\begin{array}{l}26 \text { Apr } 200822: 14 \\
\text { NIC S0618 }\end{array}$ \\
\hline Q & $\begin{array}{l}\text { Sav "Charge It" with vour cell phone } \\
\text { (chapter 2) }\end{array}$ & 0 & ALL K0605 & 3 & $\begin{array}{l}26 \text { Apr } 200804: 30 \\
\text { ALL KO } 605\end{array}$ \\
\hline 0 & $\begin{array}{l}\text { Online ElectronicStore-BestBuv(Ch14. E- } \\
\text { Business) }\end{array}$ & 2 & PEN 31576 & 11 & $\begin{array}{l}26 \text { Apr } 200802: 03 \\
\text { PEN } 31576 \rightarrow[?]\end{array}$ \\
\hline Q & $\begin{array}{l}\text { NO CELL PHONE WITHOUT HEADSET LAW IN } \\
\text { THE CAR }\end{array}$ & 0 & NAD PA582 & 5 & $\begin{array}{l}26 \text { Apr } 2008 \text { 01:53 } \\
\text { NAD PA582 }\end{array}$ \\
\hline 0 & CHAPTER 15 RATEMYPROFESSORS.COM & 0 & NAD PA582 & 4 & $\begin{array}{l}26 \text { Apr } 200801: 47 \\
\text { NAD PA582 }\end{array}$ \\
\hline Q & $\begin{array}{l}\text { Averaqe salary for people with } \\
\text { designations; CA, CMA, CGA }\end{array}$ & 0 & CHR KY 603 & 5 & $\begin{array}{l}25 \text { Apr } 200820: 03 \\
\text { CHR KY } 603 \Rightarrow \square\end{array}$ \\
\hline A & YouTube Related to B6 & 17 & AUD BI532 & 81 & 25 Apr 2008 19:47. \\
\hline
\end{tabular}

Figure 3. Main page of the forum

The ELMS captures the following real time data every time a student logs into the forum: login date, logout date, time and date of post. Other data such as views are totaled but not per user. Manual analysis of discourse is not done, but the present data provides ample information to analyze participation and interaction at the macro level as per Table 1 . Moreover, the cases that the students have generated would provide ins ight into what interests them for future use in their learning. Therefore, measurement and analysis is done as follows:

1. Participation - Macro Level: Number of posts as a function of time in the semester (for both professor's lectures and the student cases) and

2. Interaction - Macro Level: Number of posts a specific student case generated which is indicative of interaction between students.

It is worth noting that although participation measurements seem superficial in the present context (due to the requirement of minimum participation), our primary interest is from a behavioral perspective. Students are not given any due dates for participation. They have to complete their participation numbers by the exam date. So students can participate evenly throughout the semester or complete all their posts at the last minute. From a behavioral point of view this is a concept which we can call "learning engagement" which could be equivalent to the adoption of technology theory. 


\section{Discussion of Results}

Figures 4 and 5 present the cumulative posts made by students as a function of days for the professor's cases and the student cases respectively. These two figures represent the behavioral aspect of student's participation. These figures are characterized by three stages. In both cases, professor's lectures and student cases, the first stage is linear increasing participation, the second stage is parabolic (possibly) and the third is exponential. These three stages combined represent an S-Curve similarly found in adoption of technology theory. Both figures demonstrate an s-curve but with different characteristics.

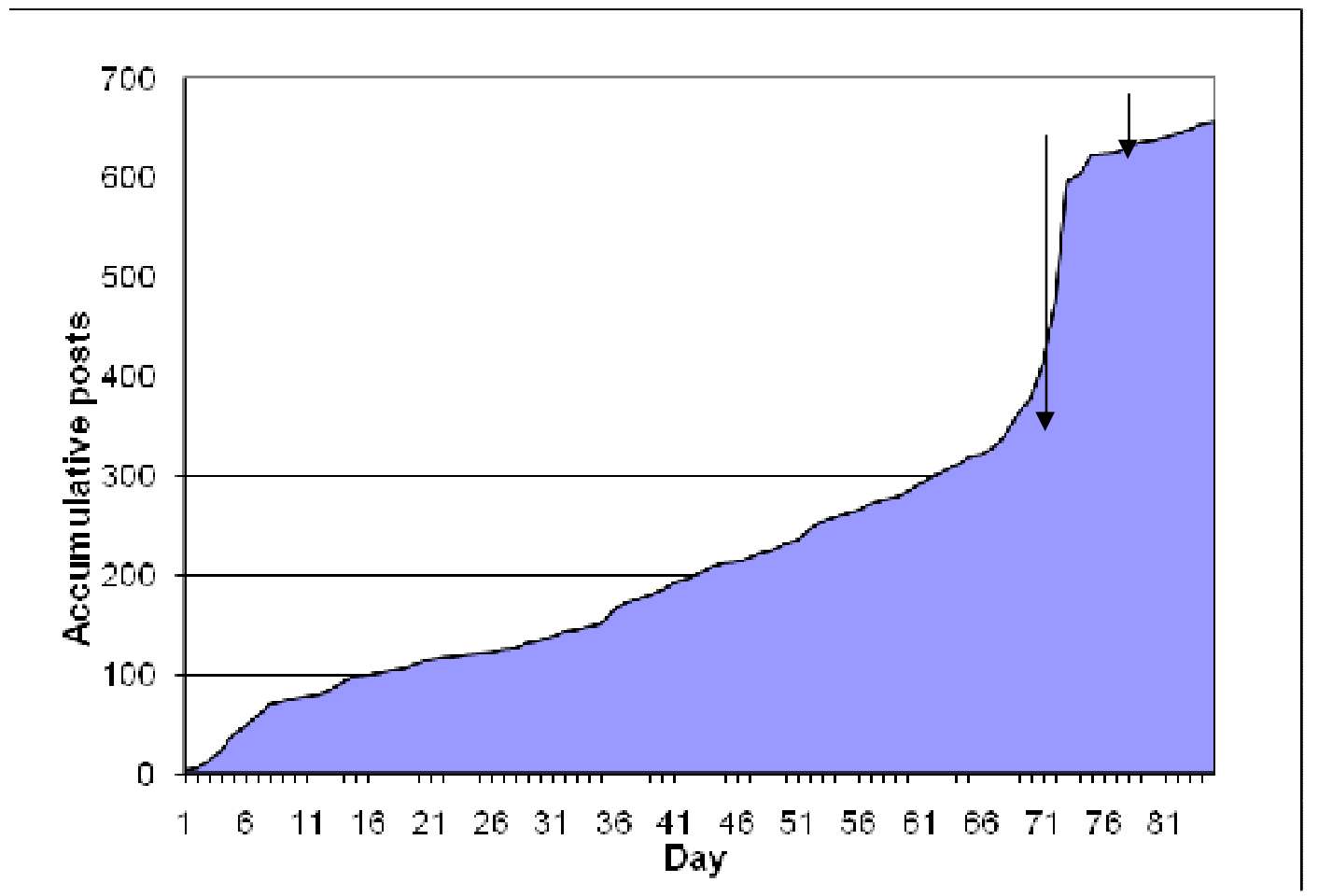

Figure 4. Daily cumulative participation for professor's cases.

The daily cumulative posts presented in Figure 4 (for the professor's cases) show that the s-curve is not well defined and can be represented by three linear functions. In stage one and for a period of approximately two months, students were participating at a rate of five posts per day. This number of 325 posts were not enough to represent the total number of students. In fact, with three hundred students and five lectures posted during those two months, there should be $300 * 5=1500$ posts (if we were to assume that students are spreading the ir participation in a timely fashion). A week into thethird month, students needed to catch up with their posting requirements and so participation increased to 46 posts per day, over a period of one week approximately. After that, and up until the end of the semester, the participation continued at the initial rate of 5 posts per day.

The daily cumulative posts presented in Figure 5 (for the student cases) show that the s-curve is well defined into the three stages. In stage one and for a period of a little less than two months, students were participating at a rate of 6.5 posts per day. Similarly to the professor's lectures, this number which is close to 400 posts was not enough to represent the total number of students. Over a period of two and a half weeks following stage 1, students' postings increased to 61 posts per day. After that, and up until the end of the semester, the participation continued to be high at 50 posts per day. 


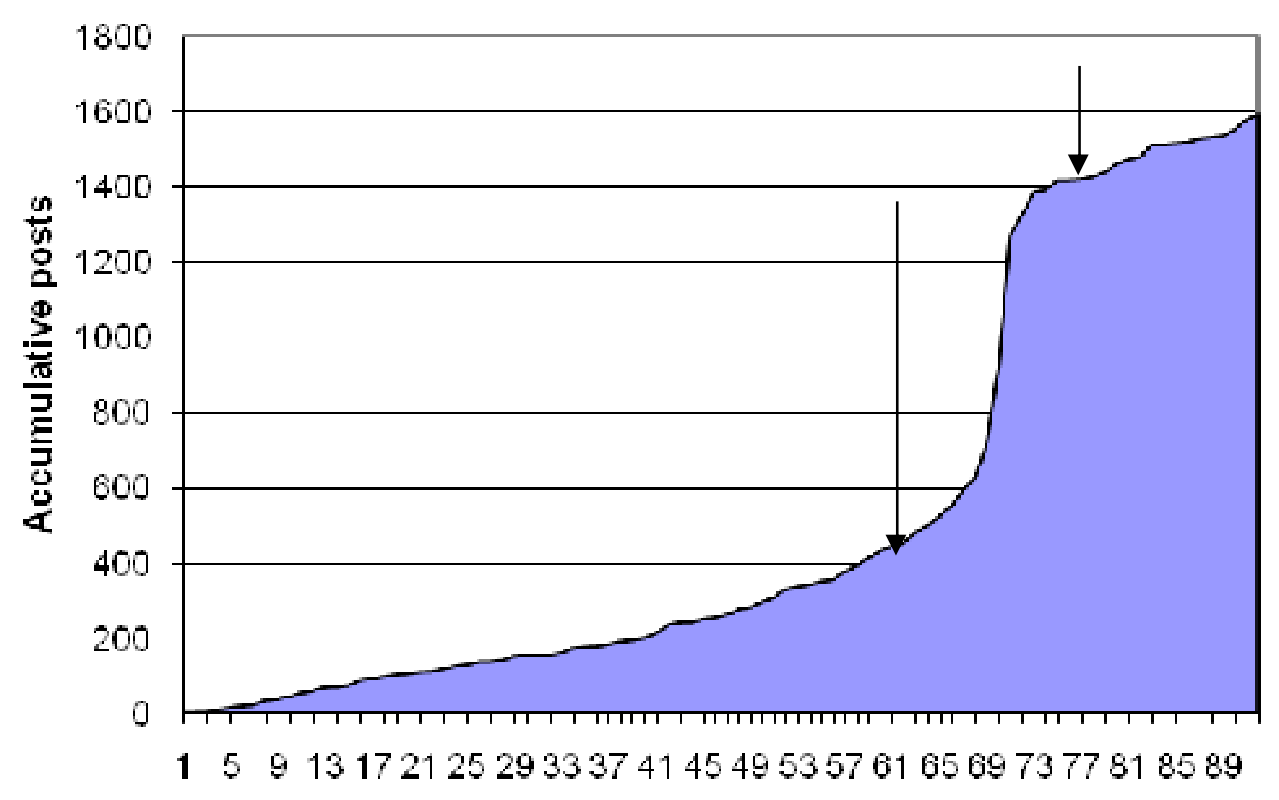

Day

Figure 5. Daily cumulative participation, for student cases.

Tables 2, 3 and 4 represent the student interaction by showing the number of views and posts generated in different topics for professor's lectures, students cases (ranked by posts) and students cases (ranked by views), respectively. Table 2 clearly shows that students were reading the professor's cases multiple times, reflecting on the content, planning what to write and then making the post. This is evident from the number of views as compared to the number of posts made. This can be considered as interactivity between the student and the content, of which the primary objective is to actually read the case multiple times, reflect, plan and then contribute. This process promotes the learning of content put into context.

Table 2. Professor's case discussion.

\begin{tabular}{|lrr|}
\hline Topic Title & Views & Posts \\
\hline Me, myself and MIS (Mandatory) & 2320 & 233 \\
\hline FUZZY BUSINESS (Mandatory) & 1449 & 218 \\
\hline Systems Development (Mandatory) & 1220 & 202 \\
\hline
\end{tabular}

Table 3 below shows the top 10 most popular student cases. These topics are ranked most popular by the level of interactivity it generated and measured by the number of posts. This represents interactivity between student and student. Table 4 is similar to table 3 but it ranks the topics with respect to the views. So here again, we observe much more views that posts, indicative of students reading many cases before deciding which one they are interested in participating. The 'views' results are a measure of student-content interaction leading to student-student interaction.

It is interesting to note that rate my professors is the top hot topic. A common topic is the social network and internet communications websites such as facebook, skype and youtube. Ethics was also a common subject matter. 
Table 3. Top 25 student cases topic interactions ranked by number posts.

\begin{tabular}{|lr|r|}
\hline Topics & Posts & Views \\
\hline RATE MY PROFESSORS chapter 15, b7 & 57 & 303 \\
\hline FRIENDSTER v.s. FACEBOOK: Ethical issues! Chapter 4 & 31 & 233 \\
\hline Concordia Escalators & 24 & 160 \\
\hline Parking Full! & 24 & 95 \\
\hline B5: The solution to long distance calls = Skype & 23 & 91 \\
\hline Facebook stalking & 23 & 90 \\
\hline Online shopping-DANGER???(ch14) & 22 & 122 \\
\hline Potholes in Montreal & 21 & 61 \\
\hline Facebook ! again & 20 & 114 \\
\hline (ch14)ONLINE DATING.....hmmmmm............ & 20 & 143 \\
\hline
\end{tabular}

Table 4. Top 25 student cases topic inte ractions ranked by vie ws.

\begin{tabular}{|lrr|}
\hline Topic & Posts & Views \\
\hline Business case 1, chapter 3, no practicality & 18 & 351 \\
\hline RATE MY PROFESSORS chapter 15, b7 & 57 & 303 \\
\hline FRIENDSTER v.s. FACEBOOK: Ethical issues! Chapter 4 & 31 & 233 \\
\hline IT, is it really worth the co\$t\$ ??? & 6 & 210 \\
\hline The world is Flat, chapter 1, question 3 & 10 & 200 \\
\hline Importance of Supply Chain Management Ch 3 & 10 & 174 \\
\hline Concordia Escalators & 24 & 160 \\
\hline CH.2 - IDENTIFYING COMPETITIVE ADVANTAGES CASE & 9 & 144 \\
\hline (ch14)ONLINE DATING.....hmmmmm............. & 20 & 143 \\
\hline Chapter 6 - Valuing Organizational Information & 17 & 132 \\
\hline
\end{tabular}

\section{Conclusions}

In this article, we presented participation and interaction results of an online discussion for um. The forum was used as one of the learning components in a management of information systems course taught online. The forum entailed two parts where students had the opportunity to participate and interact: professor's cases and student cases. These two parts had attributes that are different and hence produced different results thereby providing further insight into students' behavior and learning. All data used were actual data captured by the ELMS.

Participation was measured the number of discussions posted by the students while interaction was measured by the number posts generated in specif ic topic threads. In both cases, two sets of data namely number of posts and number of views provided insight into learning. By performing this macro-level analys is of performance and interaction within the context of the course, it was possible to better understand whether learning did occur and holistic behavior of students.

It was evident that the number of views was much more than the number of posts indicating that students were reading the posted discussions before making a decision on where and when to partic ipate/interact. This may suggest that students actually were planning the ir participation and not just placing a superficial discussion just going through the requirements. Participation had no time limitation and students were free to participate when they were ready. Analys is of their partic ipation behavior revealed that student's cumulative performance followed a normal distribution with a mean at approximately 2 months. Students gradually increased their participation and interaction for the first two months and crammed in the following couple of weeks to complete their 
posts. However, they were actually browsing the forum and monitoring the discussions already made. This behavior may suggest that students are reflecting and planning their discussions in the forum. This is a desirable outcome.

In the student cases part of the discussion forum, students were required to create 2 course related cases and participate in 4 peers cases. Although this discuss ion activity was mandatory to obtain the marks, students were given the freedom to select the topic of their interest and the topics they would like to engage in discussion. The results were desirable in two respects: the views were much more than the discussion posts and certain topics resulted in more discussion than others. An added outcome of this approach was that students identified topics of interest which could be viewed as knowledge building form the real world. These topics entailed rateyourprofessor, youtube, facebook and cellular phones.

\section{References}

Bourne, J. R. (1998). Net-learn ing: Strategies for on-campus and off-ca mpus network-enabled learn ing. Journal of Asynchronous Learning Networks, 2(2). Retrieved August 15, 2004, fro m http://www.sloanc.org/publications/jaln/v2n2/v2n2 bourne.asp

Davis, B., \& Brewer, J. P. (1997). Electronic discourse: Linguistic individuals in virtual space. Albany: State University of New York Press.

De Wever, B., Schellens, T., Valcke, M., \& Van Keer, H. (2005). Content analysis schemes to analyze transcripts of online as ynchronous discussion groups: A review. Computers and Education, 46(1), 628.

Desanctis, G., Fayard, A., Roach, M., \& Jiang, L. (2003). Learning in online foru ms. European Management Journal, 21(4), 565-577.

Deziel-Evans, L. (2000). An investigation of critical thinking in synchronous and asynchronous computer conferencing environments. Unpublished doctoral dissertation, Nova Southeastern University, Florida.

Dube, L., Bourhis, L., \& Jacob, R. (2006). Towards a typology of virtual communities of practice. Interdisciplinary Journal of Information, Knowledge and Management, 1, 69-93. Ret rieved from http://ijikm.org/Volume 1/IJIKMv1p069-093Dube.pdf

Garrison, D. R., \& Anderson T. (2003). E-learning in the 21 st Century: A framework for research and practice. London and New York: RoutledgeFalmer.

Harman, K., \& Koohang, A. (2005). Discussion board: A learning object. Interdisciplinary Journal of Knowledge and Learning Objects, 1, 67-77. Retrieved from http://ijello.org/Volu me 1/v1p067$\underline{\text { 077Harman.pdf }}$

Henri, F. (1992). Co mputer conferencing and content analysis. In A. R. Kaye (Ed.), Collaborative learning through computer conferencing (pp. 117-136). Berlin: Springer.

Irani, T. (1998). Communication potential, information richness and attitude: A study of computer mediated communication in the ALN classroom. ALM Magazine, 2(1).

Keller, J. (1987). Strategies for stimulating the motivation to learn. Performance and Instruction, 26(8), 17.

Laurillard, D. (1979). The processes of student learning. Higher Education, 8, 395-409.

Leidner, D. E., \& Jarvenpaa, S. L. (1995). The use of information technology to enhance management school education: A theoretical view. MIS Quarterly, 19(3), 265-291.

Ma, A. W. (2008). Co mputer supported collaborative learning and social creativity: A case study of fashion design. Journal of Information, Information Technology, and Organizations, 3, 17-39. Retrieved from http://jiito.org/artic les/JIITOv3p017-039Ma453.pdf 
Merriam, S. B. (2001). Qualitative research and case study applications in education (Rev. ed.). San Francisco: Jos sey-Bass.

Montero, B., Watts, F., \& Garcia-Carbonell, A. (2007). Discussion forum interactions: Text and context. System, 35, 566-582.

Saadé, G. R. (2003). Web-based educational information system for enhanced learning, (EISEL): Student assessment. Journal of Information Technology Education, (2), 267-277. Retrieved Feb, 2004 from http://jite.org/documents/Vol2/v2p267-277-26.pdf

Saadé, G. R., \& Bahli, B. (2005). The impact of cognitive absorption on perceived usefulness and perceived ease of use in on-line learning: An extension of the technology acceptance model. Information and Management, 42(2), .317-327.

Saadé, G. R, \& Huang, Q. (2008). Prototyping a learning management system for higher education. Proceedings of the Informing Science and IT Education Conference (InSITE), pp.155-165, Bulgaria. Retrieved fro $\mathrm{m}$ http://proceedings.informingscience.org/InSITE2008/InSITE08p155-165Saade461.pdf

Saadé, G. R., \& Kira, D. (2007). Mediating the impact of technology usage on perceived ease of use by anxiety. Computers and Education, 92(4), 1189-1204.

Schrire S. (2006). Knowledge building in asynchronous discussion groups: Go ing beyond quantitative analys is. Computers and Education 46, 49-70.

Sherry, L., Billig, S. H., \& Tavalin, F. (2000). Good online conversation: Build ing on research to inform practice. Journal of Interactive Learning Research, 11(1), 85-127.

Singh, G., Hawkins, L., \& Why mark, G. (2007). An integrated model of collaborative knowledge building. Interdisciplinary Journal of E-Learning and Learning Objects, 3, 85-105. Retrieved from http://ijello.org/Volu me3/IJKLOv3p085-105Singh385.pdf

Sutherland, J., Watts, F., Garcia-Carbonell, A., Montero, B., \& Eidsmo, A. (2003). Fostering a sense of community in networked environ ments: IDEELS telematic simulations. In V. Rodrigo Peñarrocha \& M. Ferrando Bataller (Eds.), Networked universities and e-learning.

Swan, K., Fredericksen, P., Pickett, A. E., Pelz, W., \& Maher, G., (2000). Bu ild ing knowledge building communities: Consistency, content and communication in the virtual classroom. Journal of Educational Computing Research, 23(4), 389-413.

Vygotsky, L. S. (1962). Thought and language. New York/London: Wiley/MIT Press.

Wallace, L., Jagose, A., \& Gunn, C., Virtual learning in cultural study: Matching subject content and instructional delivery. In S. Naidu (Ed.), Learning and teaching with technology: Principles and practices. London and Sterling, VA: Routledge, Taylor and Francis Group.

Weinberger, A., \& Fischer, F. (2005). A frame work to analy ze argu mentative knowledge construction in computer-supported collaborative learning. Computers and Education, 46(1), 71-95.

Wells, G. (1999). Dialogic inquiry: Towards a sociocultural practice and theory of education. Camb ridge, MA: Cambridge University Press.

Wertsch, J. V. (1998). Mind as action. New York, Oxford: Oxford University Press.

Yang, X., Li, Y., Tan, C., \& Teo, H. (2007). Students' participation intention in an online discussion forum: Why is computer-mediated interaction attractive? Information \& Management, 44, 456-466.

Zhang, D., Zhou, L., Briggs, R. O., \& Nunamaker J. F. (2006). Instructional video in e-learning: Assessing the impact of interactive video on learning effectiveness. Information and Management, 43(1), 15-27. 


\section{Biographies}

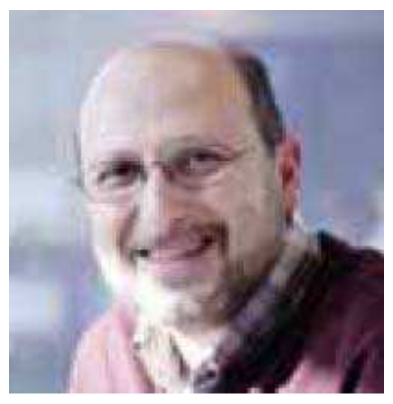

Dr. Raafat Saadé is a lecturer at the DSMIS department, John Molson School of Business, Concordia University, Canada. Dr. Saadé obtained his Ph.D. in 1995 from Concordia University. He subsequently received the Canadian National Research Council postdoctoral fellowship, which he completed at McGill University (Montreal). He has been recognized twice as a North Atlantic Treaty Organization ASI award winner. Dr. Saadé has 18 years of industrial experience (engineering, elearning and ehealth), and presently is involved in international consulting projects. He is very active in research with over 25 peer refereed journal artic les. Dr. Saadé has publis hed in top tier journals including Information and Management, JISE, Expert Systems with Applications, and Decision Sciences.

Mr. Qiong Huang is a systems developer and analyst at the John Molson School of Business at Concordia University, Montreal. Mr. Huang has over 10 years of experience in China in the development of learning management systems. He is currently completing his masters in computer science at Concordia University. Mr. Huangs interests include the development of learning management systems and efficient algorithms in artificial intelligence. 